\title{
Kommunikáció az egészségügyi teamen belüil: orvosok és szakdolgozók
}

\author{
Kollár János dr. \\ Semmelweis Egyetem, Általános Orvostudományi Kar, Magatartástudományi Intézet, Budapest
}

\begin{abstract}
Az egészségügyi teamen belüli kommunikáció meghatározó a dolgozók érzelmi, szakmai biztonságérzetének megteremtése és a gyógyítás minősége szempontjából. A tanulmány célja az orvosok és szakdolgozók megfelelő kommunikációját akadályozó tényezők feltárása annak érdekében, hogy a kommunikációs zavarokat hatékonyan ki lehessen küszöbölni. A főbb orvosi adatbázisokban, valamint általános keresőrendszerek segítségével történő kutatás módszerét alkalmaztam a jelenség elemzésére. Megállapítható, hogy egyéni, hivatásbeli és rendszerszintű tényezők is korlátozzák az orvosok és szakdolgozók kommunikációját. Ezek között szerepzavarok, bizalomhiány, hierarchiai különbségekből származó kommunikációs gátak, vezetői problémák, képzettségbeli eltérések, kiégés és szervezeten kívüli tényezők egyaránt szerepelnek. A magyarországi orvos-szakdolgozó kommunikáció hatékonyságára erősen rányomja bélyegét a munkahelyi bizonytalanságból eredő félelem, az eltérő mértékű hálapénzzel terhelt finanszírozási nehézségek sora, valamint a kiégés. Egyéni, hivatásbeli és rendszerszintû́ változtatások egyaránt szükségesek ahhoz, hogy az orvosok és szakdolgozók kommunikációja jelentősen javuljon. Az erős szervezetfejlesztési tudással megvalósított közös tréningek, közös konferenciák elősegíthetik a jobb információáramlást és a kölcsönös elismerést, összehangolódást. Orv. Hetil., 2016, 157(17), 659-663.
\end{abstract}

Kulcsszavak: orvosok, szakdolgozók, teamkommunikáció, hatékonyság, fejlesztés

\section{Communication within the health care team: doctors and nurses}

Proper communication within the health care team is especially important in terms of creating safe emotional and professional conditions for the team members and for quality healing. The aim of the study is to explore the factors that hinder appropriate communication between doctors and nurses and thus to make the effective elimination of the communication disturbances possible. Investigation in main medical databases and general search engines were used for analysing the phenomenon. It was revealed that communication between doctors and nurses is restrained by factors that can be observed on individual, professional and system levels as well. Role confusion, lack of trust, communication barriers arising from hierarchical inequalities, leadership problems, differences in qualifications, burnout and organizational problems can equally be found amongst them. The effectiveness of communication between nurses and doctors in Hungary is especially strongly influenced by the fear of losing jobs, the financial problems arising from different degree of gratuity and the phenomenon of burnout. Changes on individual, professional and system levels are equally important for significant improvement in the communication between doctors and nurses. Joint trainings based on strong organizational development skills and joint conferences could promote significantly better flow of information, mutual appreciation and harmonization.

Keywords: doctors, nurses, team communication, effectiveness, development

Kollár, J. [Communication within the health care team: doctors and nurses]. Orv. Hetil., 2016, 157(17), 659-663.

(Beérkezett: 2016. február 26.; elfogadva: 2016. március 17.)

Az egészségügyi teamen belüli helyes kommunikáció alapvető jelentőségü a betegek gyógyulása szempontjából, valamint a csapaton belüli megfelelő hivatalos és személyes viszonyok kialakítása érdekében egyaránt. Nemkülönben fontos a csapatban dolgozók érzelmi és szakmai biztonságérzetének megteremtése és fenntartása tekintetében is. A rossz kommunikáció nem csupán a teamen belüli viszonyokat rombolja, hanem ezen keresztül a beteg egészségét, életét is veszélyeztetheti [1]. Jóllehet, a megfelelő társas interakciók alapvető fontossá- 
gúak a team tagjaiként dolgozó orvosok, szakdolgozók, gyógyszerészek, rezidensek, kisegítők egymás és hivatásuk iránti elkötelezettségének elmélyítésében, jelen tanulmány keretei nem teszik lehetővé az összes kölcsönös kapcsolat górcső alá helyezését, így az orvos-szakdolgozó kommunikáció jellegzetességeire, rendellenességeire és javítási lehetőségeire fókuszáltam. Ahhoz, hogy feltárjuk, mely gátak akadályozzák a teamen belüli megfeleló információcserét, számos tényezőt kell figyelembe vennünk. Ezek között egyéni, hivatásbeli és rendszerszintü problémák egyaránt szerepelnek. Jelen tanulmány célja ezen akadályozó tényezők feltárása, tapasztalati tényeken alapuló rövid ismertetése annak érdekében, hogy az egészségügyi teamépítésben, közelebbről az orvos-szakdolgozó kommunikációban mutatkozó zavarokat hatékonyan ki lehessen küszöbölni.

\section{Módszer}

Keresést végeztem a fóbb orvosi adatbázisokban (Cochrane, PubMed, Web of Science), a Google adatbázisban, valamint alkalmaztam a Netvibes keresőszoftvert a releváns adatok felkutatása érdekében. A kereséseket 2015. december 9-18. között folytattam. A kutatást nem korlátoztam a cikkek publikációs dátuma alapján. Az alkalmazott kulcsszavak, illetve -kifejezések a következők voltak: medical, medicine team, teamwork, team building, doctor, physician, nurse, communication, orvosi, orvos, szakdolgozó, kommunikáció, teamépítés, csapatépítés, teammunka, csapatmunka és egészségügy. A keresések során a publikációk címeit, absztraktjait és kulcsszavait vettem figyelembe. A kapott eredményeket a cikk terjedelmi korlátai miatt oly módon szúrtem, hogy ha nem is teljes körü, de átfogó képet tudjak nyújtani a témáról.

\section{Eredmények}

Dinh [2] és Grant [3] kutatásai alapján a következő fóbb, az orvosok és szakdolgozók közötti kommunikációt akadályozó tényezőket gyújtöttem össze (1. táblázat).

Az orvosi vagy a szakdolgozói hivatás nem véletlenül neveztetik „hivatásnak” és nem szakmának. Az ilyen tevékenységek nyomot hagynak a személyiségben is. A szociológusok ezeket „levehetetlen szerepként” szokták emlegetni. A felfokozott önértékelés és öntudat, valamint a gyógyító szituáción kívül terjedő magabiztosság és határozottság szinte elvárt elemei e tevékenységeknek [4]. Amennyiben valaki úgy érzi, hogy képtelen megfelelni e szerepeknek, vagy nem tudja megkülönböztetni magánemberként való ténykedését hivatásbeli magatartásától, komoly szerepzavarral kell számolnia.

A kölcsönös függőségből fakadó bizalomhiány gyakori jelenség, viszont ritkán elemzett tényező az orvosszakdolgozó kapcsolatban. Cairo [5] a sürgősségi ellátásban dolgozó orvosok szakdolgozók iránti ambivalens viszonyulását vizsgálta. Megállapításai szerint az orvosok a szakdolgozók tudásszintjével, megbízhatóságával, el- kötelezettségével és képességével kapcsolatos aggodalmaikat fogalmazták meg leggyakrabban. A bizalmatlanság viszont bizalmatlanságot szül, és megnehezíti az egész gyógyítóteam munkáját [6].

Az orvosok és szakdolgozók közötti hierarchiai különbség megszokott jelenség. Problémát akkor jelent a teammunkában, ha túllép a szakmailag elfogadható kereteken. Ez megnyilvánulhat a mindennapos kommunikáció során is (például az orvos azt mondja: „X. nővér nekem dolgozik") [7], illetve, ha az orvos és a szakdolgozó nem veszik figyelembe egymás szakmailag megalapozott véleményét, ami egyben a kölcsönös tisztelet hiányát is jelzi.

A teamkommunikáció hivatásbeli korlátozó tényezői a gyógyítócsapat tagjainak a kölcsönös megállapodásokkal szembeni nyílt vagy burkolt ellenállását eredményezhetik. A bizonytalan vezetés éppúgy károsan hat a team múködésére, mint a túlkontrollált [8].

1. táblázat |Az orvosok és szakdolgozók közötti kommunikációt akadályozó főbb tényezők

\begin{tabular}{|c|c|c|}
\hline Egyéni korlátok & \multicolumn{2}{|c|}{$\begin{array}{l}\text { Az egyéni szerepek tisztázásának hiánya } \\
\text { Kölcsönös bizalom hiánya } \\
\text { Valóságos és képzelt hierarchikus szerepek közötti } \\
\text { eltérés } \\
\text { Kölcsönös tisztelet hiánya }\end{array}$} \\
\hline \multirow[t]{2}{*}{$\begin{array}{l}\text { Hivatásbeli } \\
\text { korlátok }\end{array}$} & $\begin{array}{l}\text { Elsősorban } \\
\text { vezetői megoldást } \\
\text { igénylő } \\
\text { problémák }\end{array}$ & $\begin{array}{l}\text { Kiforrott vezetés és } \\
\text { egyértelmú szabályok hiánya } \\
\text { A csoportméretból fakadó } \\
\text { problémák } \\
\text { Az együttmúködés } \\
\text { kidolgozására szánt idő hiánya } \\
\text { A különböző díjazási/ } \\
\text { jutalmazási rendszerek } \\
\text { egyeztetésének hiánya } \\
\text { Adminisztratív korlátok } \\
\text { Nem megfelelő döntéshozatali } \\
\text { struktúrák/módszerek }\end{array}$ \\
\hline & $\begin{array}{l}\text { Elsősorban } \\
\text { beosztotti } \\
\text { megoldást } \\
\text { igénylő } \\
\text { problémák }\end{array}$ & $\begin{array}{l}\text { Új dolgozó betanításának, } \\
\text { eligazításának hiánya } \\
\text { Nem megfelelő formális és } \\
\text { informális kommunikációs } \\
\text { mechanizmusok } \\
\text { A különböző képzettségi } \\
\text { szintekból fakadó nehézségek } \\
\text { Szakmai szerepzavarok, } \\
\text { bizonytalanságok } \\
\text { Az elkötelezettség hiánya } \\
\text { A csapattagok eltérő egyéni } \\
\text { motivációi } \\
\text { Eltérő egyéni kapcsolat a } \\
\text { betegekkel } \\
\text { Fásultság, kiégés } \\
\text { A felelősségvállalás hiánya } \\
\text { Előítéletek }\end{array}$ \\
\hline $\begin{array}{l}\text { Rendszerszintű } \\
\text { korlátok }\end{array}$ & \multicolumn{2}{|c|}{$\begin{array}{l}\text { Közös kommunikációs tréning és csapatépítés } \\
\text { hiánya } \\
\text { Támogatás hiánya (erkölcsi és anyagi) } \\
\text { Megfelelő visszajelző és értékelőrendszer hiánya }\end{array}$} \\
\hline
\end{tabular}


Egymás képzettségi különbségeinek figyelembevétele és tiszteletben tartása elengedhetetlen a jó teammunka kialakításához. Bizonyos feladatokat a szakdolgozók jobban el tudnak látni, mint az orvosok, és viszont [9].

Nem elhanyagolandók az új dolgozók betanításának, eligazításának hiányosságaiból fakadó kommunikációs zavarok sem. A nagymértékü fluktuáció egyre súlyosabbá teszi ezt a gondot [10].

A gyógyítóteam megfelelő taglétszáma számos tényezőtől függ, amelyek között egyaránt szerepel a beteglétszám, a szakmai ellátás igénye és a múködésre rendelkezésre álló keretösszeg. A túl nagy és a túl kicsi létszám egyaránt akadályozza a közös munkát. Minél nagyobb egy csoport, annál nehezebb koordinálni, és a tagok közötti információáramlás is annál bonyolultabb. A nagy létszám a döntéshozatali folyamatokat is lassítja [11].

Az együttmúködés kidolgozására szánt idő hiánya, a különböző díjazási/jutalmazási rendszerek egyeztetésének hiánya, a kommunikációt akadályozó bürokratikus, adminisztratív korlátok és a nem megfelelő döntéshozatali struktúrák/módszerek elsősorban vezetői hatáskörben orvosolandó problémák. Tévedés volna azt hinni azonban, hogy a nem megfelelő kommunikációs mechanizmusok javítása szintén csupán a vezető feladata lenne. Az orvosok és szakdolgozók közötti információáramlás hatékonyságának javítása személyes, vezetői és intézményi szintü feladat, amint ezt Gilardi és mtsai [12] sürgősségi osztályon végzett kutatásai is egyértelmúen igazolják. A csapatmunka hiányosságai számos okra vezethetők vissza, amelyek között szerepet játszik a csapattagok intézményi státusza, hierarchiában elfoglalt helye, a hibák és tévedések kezelése, egyéni tényezők sora (nemi különbségek, stressztolerancia), valamint több külső tényező is (felszereltség, intézményi jellemzők) [13]. A hibás kommunikációs mechanizmusok (például a le nem zárt vagy késleltetett információcsere) számos lényeges, gyakran életfontosságú információveszteségért tehetők felelőssé [14]. A betegbiztonság és a hatékony együttmúködés érdekében szervezett tréningek - mint például a Sawyer és kutatótársai [15] által létrehozott TeamSTEPPS (Team Strategies and Tools to Enhance Performance and Patient Safety) program - gördülékenyebbé teszik a csapatmunkát, pozitív szerkezeti változásokat indukálnak, serkentik a kölcsönös támogatás rendszerének kialakítását, és javítják a csapattagok közötti kommunikációt. A közös, kommunikációfejlesztő tréningek pozitív hatásait igazolják Sands és munkatársainak [16] eredményei is. Ők az empátiafejlesztést, csapatépítést és a kiégés megelőzését tűzték ki a hathetes, heti egy alkalommal történő képzésük céljául. Eredményeik szerint kezdeményezésük hatására a csapatmunka jelentős mértékben javult az egészségügyi team dolgozói között. Mash és mtsai [17] orvosokból, szakdolgozókból, valamint betegekből álló együttmúködő csoportot hívtak össze azért, hogy orvosok és szakdolgozók részvételével minél hatékonyabb gyógyítóteamet hozzanak létre. A csoport tagjai 9 hónapon át rendszeresen találkoztak, és megbeszélték a csapatmunkával kapcsolatos sarkalatos kérdéseiket. A vizsgálat eredményeképpen megállapították, hogy a gyógyítók olyan szervezetet alkotnak, amelyben - egy élő szervezethez hasonlóan - a legfontosabb szerepet az információáramlás, az együttmúködés és a változásokhoz való alkalmazkodás képessége játssza.

Az információmegosztás hatékonyságának megítélése orvosi és szakdolgozói szemszögből különböző. Knoll és Lendner [18] kvalitatív vizsgálata szerint a szakdolgozók a kommunikációs kultúra orvosok által eróltetett túlhierarchizált voltára panaszkodtak. Kifogásolták a közös döntéshozatal hiányát is, azaz, hogy véleményük szerint nem járulhattak hozzá teljes szakmai tudásukkal a fontos döntésekhez. A kórházi szakdolgozók a legtöbb esetben közvetlenebb kapcsolatban állnak a betegekkel, mint az orvosok, ezért gyakran több információval rendelkeznek a pácienseket illetően. Többnyire mégis kevesebb szerepet kapnak az információszolgáltatás területén, mintsem tudásuk és képességük alapján megérdemelnének [19].

Az orvosok és szakdolgozók szakmai kapcsolatára rányomja bélyegét a kiégés jelensége is. Li és mtsai [20] 11 ország 23446 szakdolgozójának kérdő́ves vizsgálata során arra a következtetésre jutottak, hogy a szakdolgozói munka a kiégés tekintetében különösen érintett. Ennek egyik oka a betegekkel közvetlen kapcsolatban állók érzelmi megterhelése, másik fontos oka pedig a szakdolgozók tudásának, szakértelmének negligálása az orvosok részéről. Az egy fóre jutó betegek egyre nagyobb száma, valamint az említett terhek miatti fluktuáció szintén nagymértékben hátráltatja a megfelelő egészségügyi ellátás biztosítását [21].

A burnout jelensége az orvosok körében is egyre gyakoribb. Az egészségügy iránti fokozott médiaérdeklődés és a betegek részérôl tapasztalható erősödő kritikus hangok mind nehezebbé teszik az egyéni felelősségvállalás elviselését [22]. A szüntelen maximalizmus, az elvárásoknak való állandó megfelelés, az ennek ellenére fennálló hibázás veszélye, a személyes sérülékenység és a csökkent elismerés egyaránt növeli a kiégés kockázatát [23]. $\mathrm{Az}$ ezzel kapcsolatos alkoholprobléma és öngyilkossági veszély szintén nem elhanyagolandó [24]. Ennek megelőzésére alkalmazott pozitív példát találhatunk Dhingra és mtsai [25] vizsgálatában, akik már az orvosi egyetemen bevezetett rezilienciatréning segítségével tettek kísérletet a később esetlegesen jelentkező kiégés megelőzésére. Weng és kutatócsoportja [26] azt találta, hogy a magasabb érzelmi intelligenciájú orvosok között ritkább volt a kiégés jelensége. A „tudatos jelenlét” (mindfulness) elsajátítását, a hivatásgyakorlók közötti élménymegosztás ösztönzését célul tűző kiscsoportos tréningek szintén segítik a kiégés elkerülését [27]. A teamen belüli közös tréningek egyben elmélyíthetik a közös célok iránti elkötelezettséget, és tisztázhatják a csapattagok munkavégzéssel kapcsolatos egyéni, eltérő motivációit [28], egyben képesek csökkenteni az egymás hivatásgyakorlásával kapcsolatos elöítéleteket is [29]. 
Ahhoz, hogy a kommunikációs szinten bekövetkezó változásokat, valamint ezek betegellátásra gyakorolt hatását mérhetővé tegyük, megfelelő visszajelző és értékelőrendszerre is szükség van. Ennek alapját képezhetik a betegek és a dolgozók körében végzett kutatási eredmények $[30,31]$.

A magyarországi helyzetet a fentieken kívül meghatározza a munkahelyi bizonytalanságokból [32], az áthelyezés, jövedelemcsökkenés, a munkahely elveszítése miatti félelemből [33] fakadó problémák által gerjesztett kommunikációs feszültségek halmaza is. Mindezt tetézi a már évi 50-100 milliárd forintra rúgó hálapénzekből származó bevételek eltérő mértéke okozta nézeteltérések és ellentétek szövevényes rendszere [34]. Az egészségügyi dolgozók körében tapasztalható kiégés és depreszszió felismerése, megelőzése és kezelése Magyarországon is elsőrendû feladat kellene, hogy legyen [35].

\section{Megbeszélés}

Az orvosok és szakdolgozók megfelelő kommunikációjának biztosítása érdekében egyéni, hivatásbeli és rendszerszintú feladatok várnak megoldásra. A kommunikációt akadályozó tényezők között egyaránt szerepelnek olyanok, amelyekre sem az orvosoknak, sem a szakdolgozóknak nincs közvetlen ráhatásuk (gazdasági helyzet, kórházak felszereltsége, technikai feltételek), de olyanok is, amelyek képzésekkel, a kommunikációáramlást segító tréningekkel hatékonyan kezelhetők. Érdemes fokozott figyelmet fordítani arra, hogy a jelenlegi helyzet ne alakítson ki egyfajta tanult tehetetlenséget ezen a téren. Tudatosítani kell az orvosok és szakdolgozók személyes felelősségét, valamint mozgásterét, hogy a betegellátás színvonala és saját érzelmi, hangulati állapotuk egyaránt javulhasson.

A szakdolgozók által birtokolt információk jelentőségét nem szabad alábecsülni. A betegekkel intim közelségben dolgozó szakdolgozók kiégési veszélyét növeli, ha az érzelmi forrásaikat meghaladó empátiát igyekeznek gyakorolni a betegek és munkatársaik irányában. Súlyosbítja a helyzetet, ha úgy érzik, hogy tudásukat, szakértelmüket figyelmen kívül hagyják vagy nem értékelik kellőképpen. Mindez az egészségügyi ellátás színvonalát is rontja. A kiégés, sajnos, az orvosok körében is gyakori jelenség. A „nehéz betegekkel” való bánásmód, a hivatással kapcsolatos kívánalmak iránti tökéletes megfelelés igénye, a fejlettebb országok által nyújtott nagyobb anyagi és erkölcsi megbecsülés és a honi helyzet közötti szakadékból fakadó frusztráció, a hibák és tévedések árnyéka rányomja bélyegét a hivatásgyakorlók életére.

Nyilvánvaló tény, hogy csak az a gyógyító képes hatékonyan segíteni másoknak, aki önmaga is kiegyensúlyozott, a különböző stresszorokat hatékonyan kezelni képes személy. A - fooként a tehetetlenség érzéséből fakadó - kezeletlen stressz akadályozza a segítő munkáját. E veszély elhárítása érdekében érdemes volna először közös stresszkezelő, majd közös csapatépítő, kommuniká- ciófejlesztő tréningeket szervezni orvosok és szakdolgozók számára. Ezek segítségével csökkenthető a hivatásgyakorlókra egyre inkább jellemző fásultság, megelőzhető a kiégés, lebonthatók az egymással szembeni előítéletek, javítható a motiváció, a csapat és a hivatás iránti elkötelezettség. Tekintettel arra, hogy a hierarchiai korlátok a közös tréningeken komoly kommunikációs gátakat képezhetnek, érdemes e képzések lebonyolítását képzett, az egészségügy területén jártas, mind az orvosok, mind a szakdolgozók által elfogadott és elismert szakemberekre bízni.

A munkahelyi szintű beavatkozásokon kívül rendszerszintü változtatásokkal is lehetne javítani az orvosok és szakdolgozók egymás iránti kölcsönös bizalmának fejlesztését. Ilyen lehetne közös konferenciák rendezése, amely egyaránt segítené az egyes hivatások közötti információáramlást, egymás munkájának jobb megismerését és elismerését, az egymástól való tanulást, valamint a kölcsönös egymásra utaltságot hangsúlyozó „egy hajóban evezünk" tudat elmélyítését.

A változások mérhetősége és követhetősége érdekében érdemes kidolgozni a betegek és a dolgozók visszajelzésein alapuló minőségértékelő rendszert is.

Anyagi támogatás: A közlemény megírása anyagi támogatásban nem részesült.

A szerző a közlemény végleges változatát elolvasta és jóváhagyta.

Érdekeltségek: A szerzőnek nincsenek érdekeltségei.

\section{Irodalom}

[1] Chatman, I. J. (ed.): The Joint Commission Guide to Improving Staff Communication. 2nd ed. Joint Commission Resources, Oakbrook Terrace, 2005. http://www.jcrinc.com/assets/1/14/GISC09_Sample_Pages1.pdf

[2] Dinh, T.: Improving Primary Health Care Through Collaboration: Briefing 2 - Barriers to successful interprofessional teams. 2012. http://www.wrha.mb.ca/professionals/collaborativecare/files/IPHCTC-Briefing2.pdf

[3] Grant, R. W., Finnocchio, L. J., and the California Primary Care Consortium Subcommittee on Interdisciplinary Collaboration: Interdisciplinary Collaborative Teams in Primary Care: A Model Curriculum and Resource Guide. Pew Health Professions Commission, San Francisco, 1995.

[4] Matekovits, Gy.: The doctor and his patient on the common bedside of minorities. [Orvos és betege a kisebbség közös betegágyán.] Korunk, 1997, 8(2), 74-77. http://epa.oszk.hu/00400 /00458/00086/1997honap2cikkl244.htm [Hungarian]

[5] Cairo, M. J.: Emergency physicians' attitudes toward the emergency nurse practitioner role: validation versus rejection. J. Am. Acad. Nurse Pract., 1996, 8(9), 411-417.

[6] Rosenstein, A. H.: Nurse-physician relationships: Impact on nurse satisfaction and retention. Am. J. Nurs., 2002, 102(6), 26-34.

[7] Conn, L. G., Oandasan, I. F., Creede, C., et al.: Creating sustainable change in the interprofessional academic primary care setting: an appreciative inquiry approach. J. Res. Interprofess. Pract. Educ., 2010, 1(3) 284-300. 
[8] Cheng, C., Bartram, T., Karimi, L., et al.: The role of team climate in the management of emotional labour: implications for nurse retention. J. Adv. Nurs., 2013, 69(12), 2812-2825.

[9] West, S. L.: Physical assessment: whose role is it anyway? Nurs. Crit. Care, 2006, 11(4), 161-167.

[10] Cooney, A. T.: An orientation program for new graduate nurses: the basis of staff development and retention. J. Contin. Educ. Nurs., 1992, 23(5), 216-219.

[11] Harrison, T. R., Williams, E. A. (ed.): Organizations, communication, and health. Routledge, New York, 2016.

[12] Gilardi, S., Guglielmetti, C., Pravettoni, G.: Interprofessional team dynamics and information flow management in emergency departments. J. Adv. Nurs., 2014, 70(6), 1299-1309.

[13] Hunziker, S., Johansson, A. C., Tschan, F., et al.: Teamwork and leadership in cardiopulmonary resuscitation. J. Am. Coll. Cardiol., 2011, 57(24), 2381-2388.

[14] Parush, A., Kramer, C., Foster-Hunt, T., et al.: Communication and team situation awareness in the OR: Implications for augmentative information display. J. Biomed. Inform., 2011, 44(3), $477-485$.

[15] Sawyer, T., Laubach, V. A., Yamamura, K., et al.: Improvements in teamwork during neonatal resuscitation after interprofessional TeamSTEPPS training. Neonatal Netw., 2013, 32(1), 26-33.

[16] Sands, S. A., Stanley, P., Charon, R.: Pediatric narrative oncology: interprofessional training to promote empathy, build teams, and prevent burnout. J. Support. Oncol., 2008, 6(7), 307-312.

[17] Mash, B. J., Mayers, P., Conradie, H., et al.: How to manage organisational change and create practice teams: experiences of a South African primary care health centre. Educ. Health (Abingdon), 2008, 21(2), 132-146.

[18] Knoll, M., Lendner, I.: Nurses' perspective on interprofessional communication on an intensive care unit. Pflege, 2008, 21(5), 339-351.

[19] Weber, H., Stöckli, M., Nübling, M., et al.: Communication during ward rounds in internal medicine. An analysis of patientnurse-physician interactions using RIAS. Patient Educ. Couns., 2007, 67(3), 343-348

[20] Li, B., Bruyneel, L., Sermens, W., et al.: Group-level impact of work environment dimensions on burnout experiences among nurses: a multivariate multilevel probit model. Int. J. Nurs. Stud., 2013, 50(2), 281-291.

[21] Gaal, I.: Beyond medicine. Patients, relatives, physicians and nurses on health care. [Túl a medicinán. Betegek, hozzátartozók, orvosok, ápolók az egészségügyről.] http://www.hospicehaz.hu/assets/nyitotanulmany.pdf [Hungarian]

[22] Ham, C., Coulter A.: Explicit and implicit rationing: taking responsibility and avoiding blame for health care choices. J. Health Serv. Res. Policy, 2001, 6(3), 163-169.
[23] Gazelle, G., Liebschutz, J. M., Riess, H.: Physician burnout: coaching a way out. J. Gen. Intern. Med., 2015, 30(4), 508-513.

[24] Hegerl, U.: Burnout - alcohol problems - risk of suicide. Role reversal: the doctor as patient. MMW Fortschr. Med., 2007, 149(27-28), 26-27.

[25] Dhingra, M., Tewari, R., Li, M.: Resilience training in medical school: the solution to doctor burnout? Med. Teach., 2016, 38(3), 319-320. (Epub 2015 Nov 11)

[26] Weng, H. C., Hung, C. M., Liu, Y. T., et al.: Associations between emotional intelligence and doctor burnout, job satisfaction and patient satisfaction. Med. Educ., 2011, 45(8), 835-842.

[27] Siedsma, M., Emlet, L.: Physician burnout: can we make a difference together? Crit. Care, 2015, 19, 273. http://ccforum.biomedcentral.com/articles/10.1186/s13054-015-0990-x

[28] Brunetto, Y., Farr-Wharton, R., Shacklock, K.: Communication, training, well-being, and commitment across nurse generations. Nurs. Outlook, 2012, 60(1), 7-15.

[29] Randall, A.: No more Mr. Bad Guy, please. Prejudices often get in the way of managers and nurses working effectively as a team. Nurs. Times, 2001, 97(3), 27.

[30] Eckbardt-Abdulla, R.: Evaluation of patient satisfaction as quality assurance measure in the hospital. Pflege, 2007, 20(3), 137-147.

[31] Li, M., Huang, C., Lu, X., et al.: Evaluation of medical staff and patient satisfaction of Chinese hospitals and measures for improvement. Biosci. Trends, 2015, 9(3), 182-189.

[32] Németh, A., Lantos, K., Bársony Kis, K.: The effect of work uncertainty on burnout and health of nurses. [Munkahelyi bizonytalanság hatása a kiégésre és az egészségre ápolók körében.] Nővér, 2015, 28(2), 11-16. [Hungarian]

[33] Németh, A., Betlehem, J., Lampek, K.: The health care changes affected the everyday lives of nurses. [Egészségügyi változások hatása az ápolók mindennapjaira.] Nővér, 2013, 26(6), 18-25. [Hungarian]

[34] Balázs, P.: Gratuity for doctors: what is the secret of our opportunism? [Orvosi hálapénz: mi a megalkuvásunk titka?] Lege Artis Medicinae, 2013, 23(2), 144-149. [Hungarian]

[35] Ádám, Sz., Cserbáti, Z., Mészáros, V.: High prevalence of burnout and depresion may increase the incidence of comorbidities among Hungarian nurses. [A magyar egészségügyi szakdolgozók körében megfigyelhető gyakori kiégés és depresszió megnövelheti számos betegség megjelenésének az esélyét.] Ideggyogy. Sz., 2015, 68(9-10), 301-309. [Hungarian]

(Kollár János dr., Budapest, Nagyvárad tér 4. XX. emelet, 1089 e-mail: janoskollar@gmail.com) 